\title{
Working
}

Paper 


\title{
Inward and Outward Spillovers
}

\section{in the SACU Area}

Jorge Iván Canales-Kriljenko, Farayi Gwenhamo,

\author{
and Saji Thomas
}

INTERNATIONAL MONETARY FUND 


\title{
IMF Working Paper
}

\author{
African Department
}

Inward and Outward Spillovers in the SACU Area

Prepared by Jorge Ivan Canales-Kriljenko, Farayi Gwenhamo, and Saji Thomas

Authorized for distribution by Calvin McDonald

January 2013

\section{This Working Paper should not be reported as representing the views of the IMF.}

The views expressed in this Working Paper are those of the author(s) and do not necessarily represent those of the IMF or IMF policy. Working Papers describe research in progress by the author(s) and are published to elicit comments and to further debate.

\begin{abstract}
Spillovers from South Africa into the other members of the Souther Africa Customs Union (known as the BLNS for Botstwana, Lesotho, Namibia, and Swaziland) are substantial reflecting sizeable real and financial interlinkages. However, shocks to real GDP growth in South Africa do not seem to systematically affect growth developments in BLNS countries as a group. Nevertheless, vector autoregressions, which allow country-specific parameters, suggest some strong spillovers onto the smaller economies.
\end{abstract}

JEL Classification Numbers: F14, F23, F42, O55

Keywords: Spillovers; Sub-Saharan Africa; SACU area

Author's E-Mail Address: jcanaleskriljenko@imf.org; fgwenhamo@imf.org; sthomas3@imf.org 


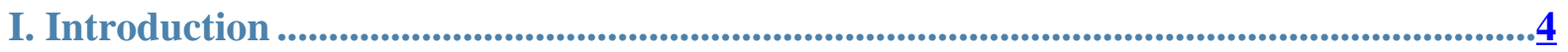

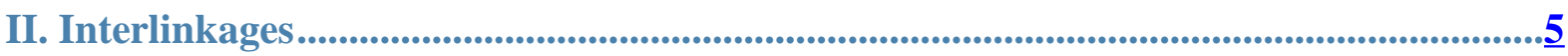

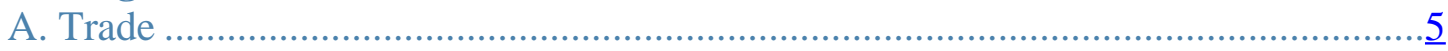

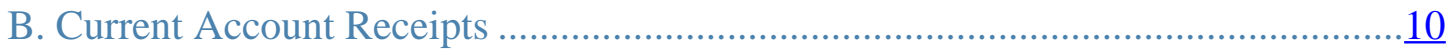

C. Foreign Direct Investment..................................................................................

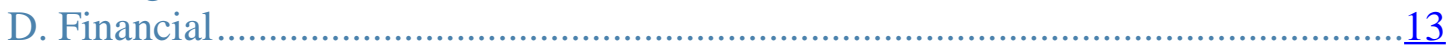

E. Monetary and Exchange Policies ....................................................................14

F. Fiscal Policies and Customs Revenue Sharing ......................................................14

III. Macroeconomic Comovements ............................................................................15

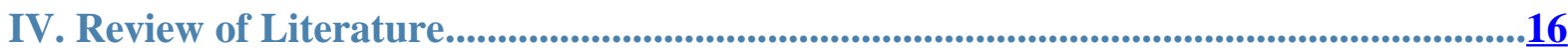

V. Panel Data Evidence ..........................................................................................................17

VI. Spillovers Evidence from Vector Autoregressions .....................................................19

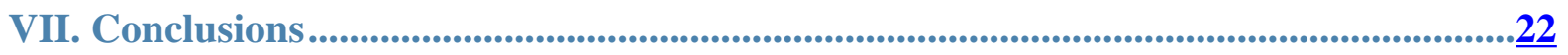

Tables

1. Bilateral Trade with South Africa, 2010 …....................................................................

2. Sub-Saharan Africa: Composition of Current Account Receipts, 2010 ..............................10

3. Sub-Saharan Africa: Official Development Assistance from OECD Countries ...................10

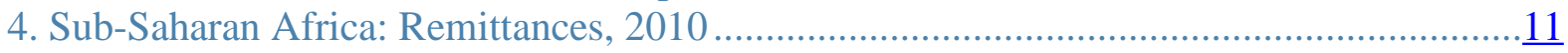

5. Sub-Saharan Africa: Foreign Direct Investment Stocks from Selected Countries, 2010 ....12

6. Sub-Saharan Africa: Key Nonfinancial South African Firms Operating in the Region.......12

7. Sub-Saharan Africa: Selected Pan-African Financial Groups, 2011 .................................13

8. Sub-Saharan Africa: Cross-border Banking Operations with South Africa, 2010 ...............14

9. Sub-Saharan Africa: Contemporaneous Correlation with World Macroeconomic

Developments, 1990-2011

10. Sub-Saharan Africa: Contemporaneous Correlation with South African

Macroeconomic Developments, 1990-2011 …............................................................ 16

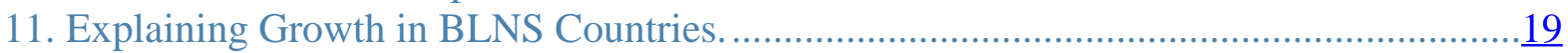

12. Model 1 and 2-Impulse Response Functions .........................................................

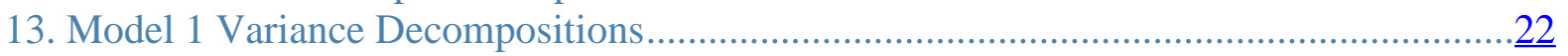

\section{Figures}

1. Sub-Saharan Africa: Intra Sub-Saharan Africa Trade Distribution: 1980-2010................... 4

2. Intra Sub-Saharan Africa Trading Network, 2010 ...............................................................

3. South Africa Trading Network with Key Global Partners, 20101 .......................................

4. SACU Countries: Trading Network with Key Global Partners, 2010 ……............................ 8

5. Key Global Partners: Trading Network with SACU Partners, 2010 ................................... 9

6. SACU: Country Share of Customs Receipts ………......................................................... 
7. Swaziland: Fiscal Policy

References 


\section{INTRODUCTION}

South Africa is a prime candidate for studying spillovers. The largest sub-Saharan Africa economy, accounting for over a third of Sub-Saharan Africa's GDP and about 40 percent of its exports, has strong financial and trade links to the global economy and other sub-Saharan Africa countries. It is subject to inward spillovers from shocks to advanced economies and other emerging markets (Canales-Kriljenko, 2011). South Africa has one of the most liquid emerging markets and shocks to global financial conditions rapidly filter into South African domestic financial variables. South African GDP is closely correlated to world GDP, a correlation that has increased over the last few decades. Through trade and financial channels, it could in principle also retransmit some of those shocks to other sub-Saharan Africa countries, giving rise to outward spillovers. Arguably, the scope for spillovers within the region has increased with the expansion of intraregional trade over the last decade, including in South Africa (Figure 1).

Figure 1. Sub-Saharan Africa: Intraregional Trade Distribution: 1980-2010 (Percent of each Sub-Saharan Africa-country GDP)

20

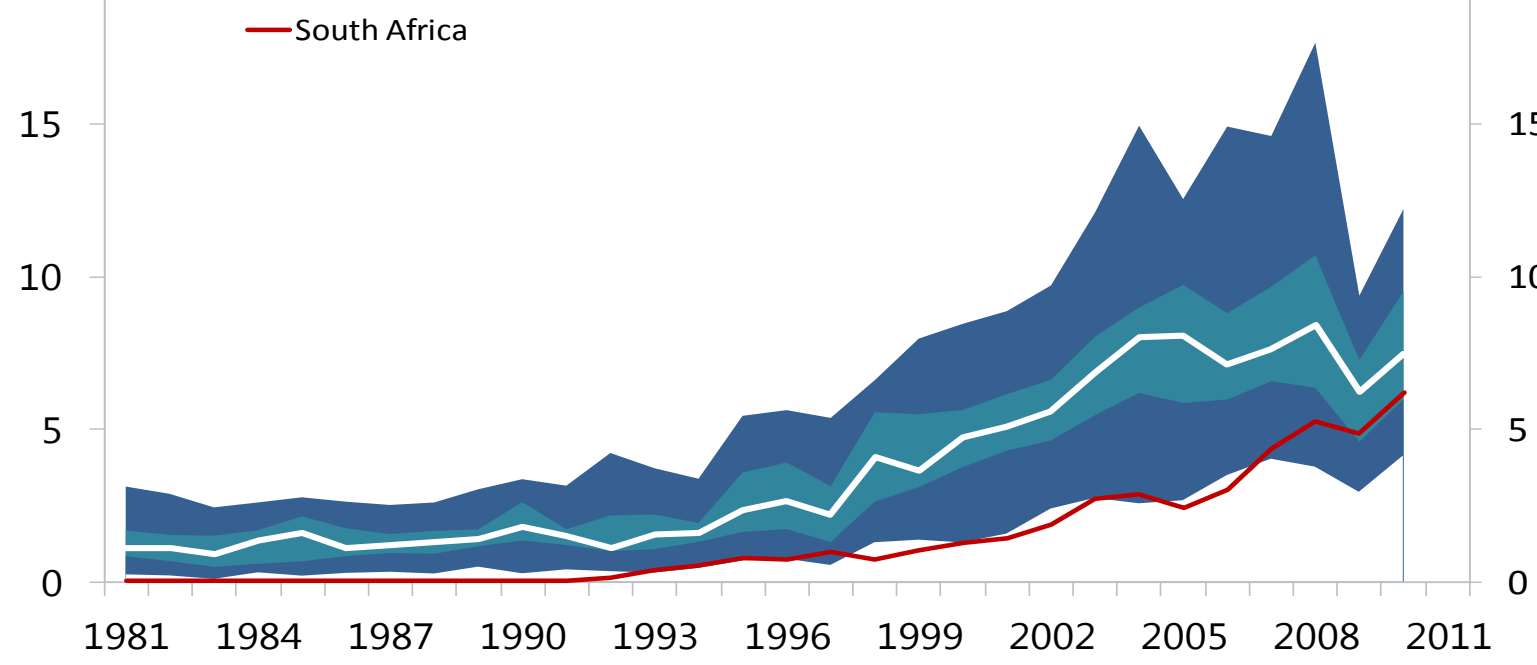

\section{Sources: IMF Direction of Trade Statistics}

Shaded areas reflect the three center quintiles of the distribution. The white line represents the median.

Outward spillovers from South Africa to other members of the Southern Africa Customs Union (SACU) could, in principle, be particularly strong. Customs revenues depend heavily on South African imports and account for a substantial amount of fiscal revenue in most BLNS countries (Botswana, Lesotho, Namibia, and Swaziland). In addition, most BLNS members, except Botswana, peg their currencies to the South African rand, in practice, adopting monetary policy decisions from the South African Reserve Bank. South Africa is also the main trading partner of the smaller members (Lesotho and Swaziland), accounting for about 80 percent of their exports and an even higher share of imports. Anecdotal evidence suggests that remittances from South Africa to some BLNS countries may also be significant. Moreover, South African financial groups are the dominant players in the financial markets of the region, spanning banking, pension, insurance, and wealth management services, whose 
treasury and risk management decisions tend to be centralized in Johannesburg. These institutions may help channel foreign direct investment from South Africa into the region.

In light of the above discussion, this paper uses several approches to examine the nature and magnitude of spillovers from South Africa to the BLNS countries. The analysis also helps to determine if South Africa acts as a conduit in the transmission of external shocks from the world to the BLNS. The remainder of the paper is organised as follows. Section II describes the macro-financial linkages between South Africa and the BLNS. Section III looks at the macroeconomic comovements using simple correlations. Sections IV and V employ panel data analysis and country specific vector autoregressive (VAR) estimations respectively to empirically examine the magnitude of spillovers. Lastly, section VII concludes the paper.

\section{INTERLINKAGES}

Close real and financial interlinkages are potentially an important source of spillovers in the region. These include exports of goods and services, remittances, foreign direct investment, cross-border banking flows, and importantly, the SACU customs revenue formula.

\section{A. Trade}

Traditional trade channels are an important channel of contagion. The analysis in this paper is done with available data, which is not readily available and may be subject to significant uncertain coverage. Significant differences exist among the scarce sources and an attempt has been made to reconcile them.

In relative terms, however, South Africa is relatively a more important market destination for the BLNS countries than vice versa, although significant country differences exist. Most intra SACU trade takes the form of South African exports into the region. In 2011, this accounted for over 80 percent of the intra SACU trade. Total intra SACU exports of BLNS countries amounted to 16 percent of intra SACU trade, while total intra SACU imports of BLNS countries accounted for about 50 percent of total intraregional trade. South Africa exports to BLNS countries about five times of the amount it imports from them (Table 1).

Table 1. Bilateral Trade with South Africa, 2010

(Percent of counterpart or South Africa's GDP, exports, or imports)

\begin{tabular}{|c|c|c|c|c|c|c|c|c|c|}
\hline & \multicolumn{5}{|c|}{ POINT OF VIEW OF COUNTRY } & \multicolumn{4}{|c|}{ POINT OF VIEW OF SOUTH AFRICA } \\
\hline & \multicolumn{2}{|c|}{ Exports } & \multicolumn{2}{|c|}{ Imports } & \multirow{2}{*}{$\begin{array}{l}\text { Trade } \\
\text { balance } \\
\% \text { GDP }\end{array}$} & \multicolumn{2}{|c|}{ Exports } & \multicolumn{2}{|c|}{ Imports } \\
\hline & $\%$ GDP & $\%$ exports & $\%$ GDP & \% imports & & $\% \mathrm{GDP}$ & $\%$ exports & $\%$ GDP & \% imports \\
\hline \multicolumn{10}{|l|}{$\underline{S A D C}$} \\
\hline \multicolumn{10}{|c|}{ SACU } \\
\hline \multicolumn{10}{|c|}{ South Africa } \\
\hline Botswana & 4.1 & 13.2 & 27.7 & 86.3 & -23.6 & 1.1 & 4.8 & & \\
\hline Lesotho & 15.3 & 38.9 & 78.1 & 93.7 & -62.8 & & 2.1 & & \\
\hline Namibia & 11.0 & 31.4 & 31.4 & 71.0 & -20.4 & 1.0 & 4.3 & & \\
\hline Swaziland & 27.4 & 58.2 & 56.8 & 96.5 & -29.5 & & 2.5 & & \\
\hline
\end{tabular}

Source: Direction of Trade Statistics, United Nations Comtrade database, and country authorities.

${ }^{1}$ Color code: White (below 1 percent), green (between 1 and 10 percent), orange (between 10 and 20 percent), red (above 20 percent). The three dots indicate that data is not available. 
South Africa is at the center of sub-Saharan Africa intraregional trade, and the BLNS countries are among the most exposed to disruptions in South Africa's ability or desirability to import. Although SACU countries have trade deficits with South Africa, their exports to South Africa are a significant share of their GDP (Figure 2).

\section{Figure 2. Intra Sub-Saharan Africa Trading Network, 2010 ${ }^{1}$}

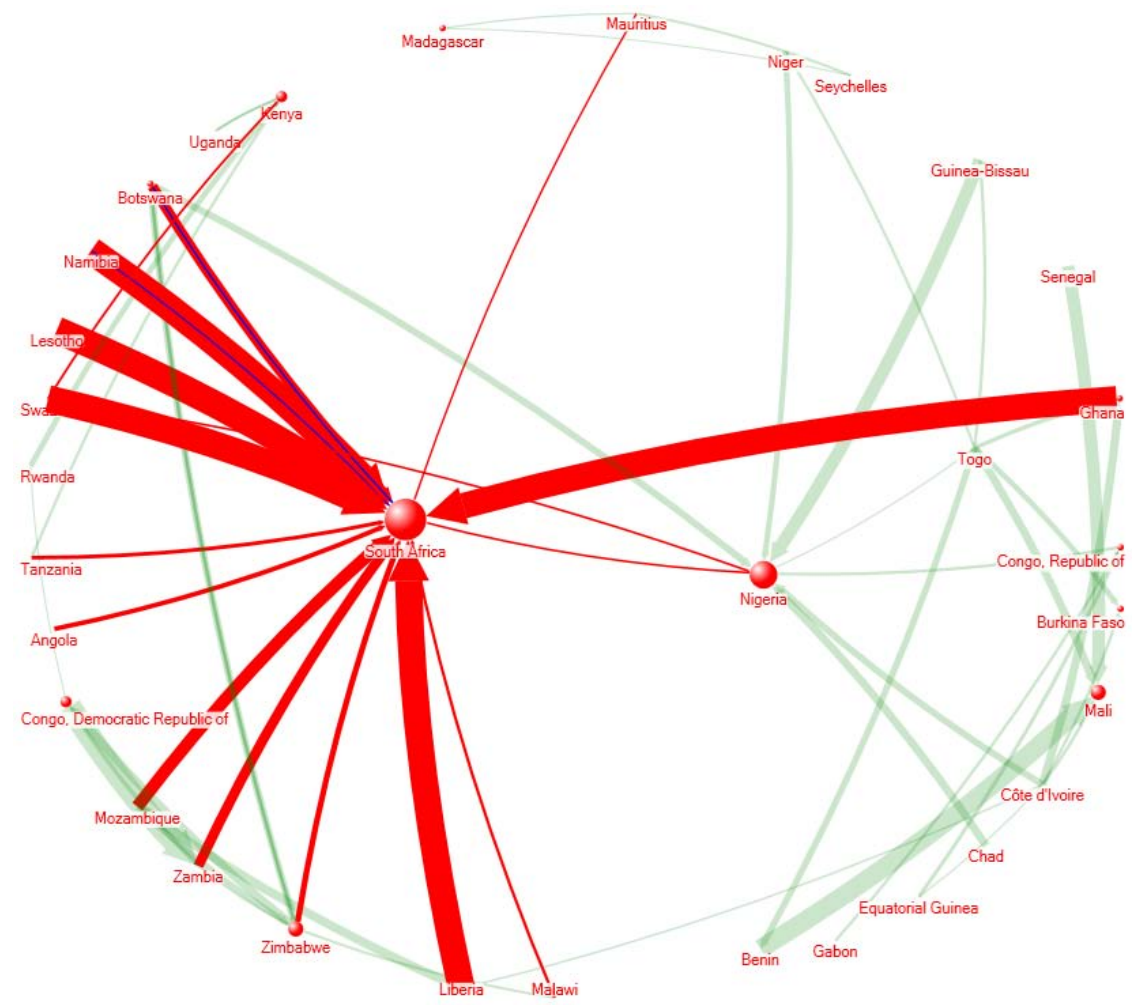

\footnotetext{
${ }^{1}$ Arrows indicate direction of trade. Red lines indicate bilateral sub-Saharan Africa trade involving South Africa. Arrow width represents bilateral trade size in percent of exporters GDP.
}

South Africa's main single-country export destinations are advanced economies. The most important is the euro area, followed by China, the United Kingdom, the United States, and Japan. Negative shocks to advanced economies will affect South Africa's income and its potential to import from the region. Through this channel, shocks to advanced economies may be retransmitted, in part, to economies which depend on South Africa as a crucial export destination, including the BLNS (Figure 3).

BLNS countries have other trading partners besides South Africa. For Botswana, the United Kingdom is more important than South Africa, while Nigeria, Zimbabwe, and the United States are important market destinations. For Lesotho, the only important market destination is South Africa. For Namibia, South Africa is the main trading partner, but China is fairly important, while the United States is important. On the export side, Swaziland has relatively important market destinations in advanced economies (Figure 4). 
Figure 3. South Africa Trading Network with Key Global Partners, 2010 ${ }^{1}$

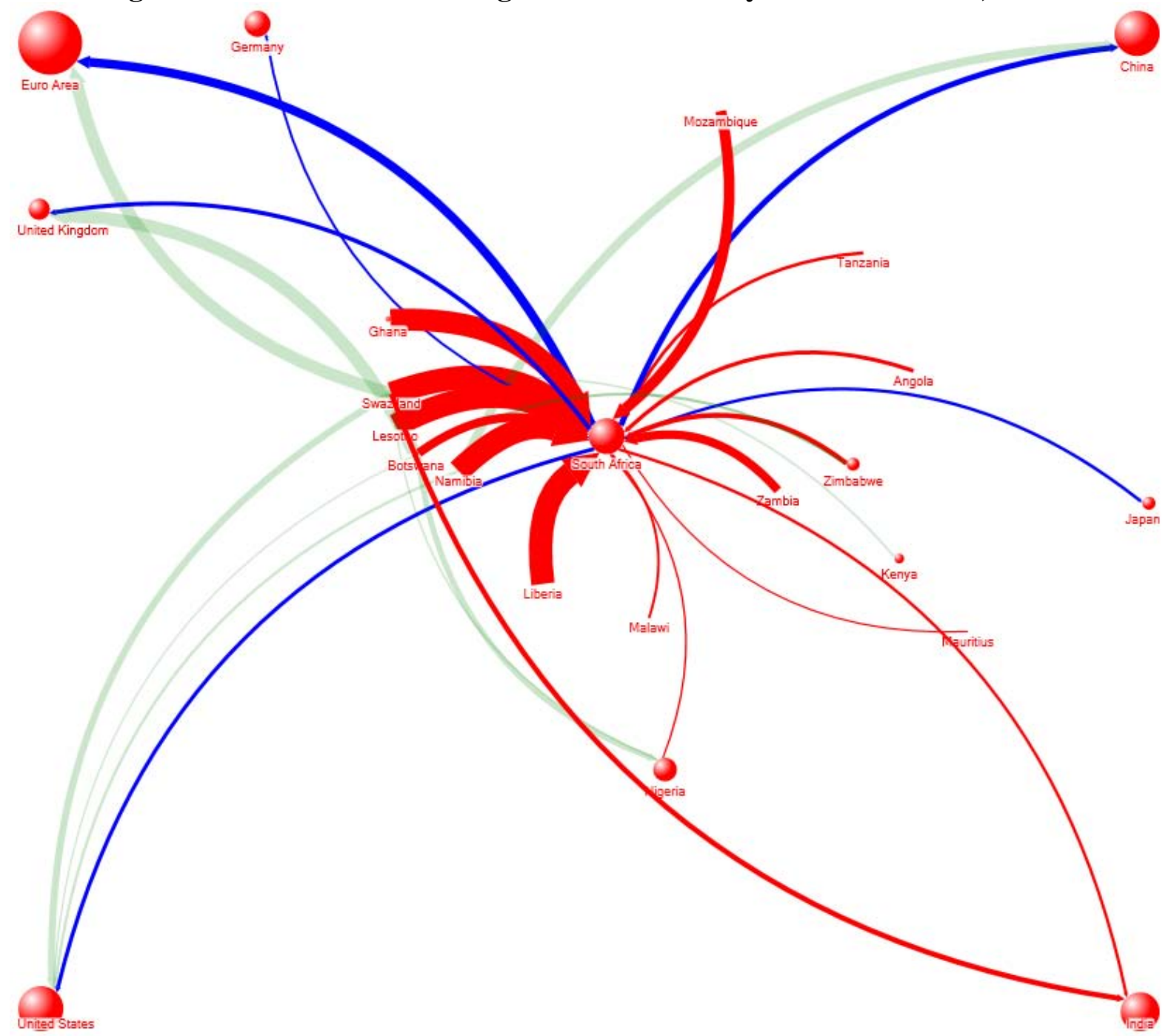

${ }^{1}$ Arrows indicate direction of trade. Red lines indicate exports to South Africa, while blue lines represent exports from South Africa to global trading partners. Green lines represent bilateral trade of other sub-Saharan Africa countries. Arrow width represents bilateral trade size in percent of exporters GDP. 
Figure 4. SACU Countries: Trading Network with Key Global Partners, 2010 ${ }^{1}$

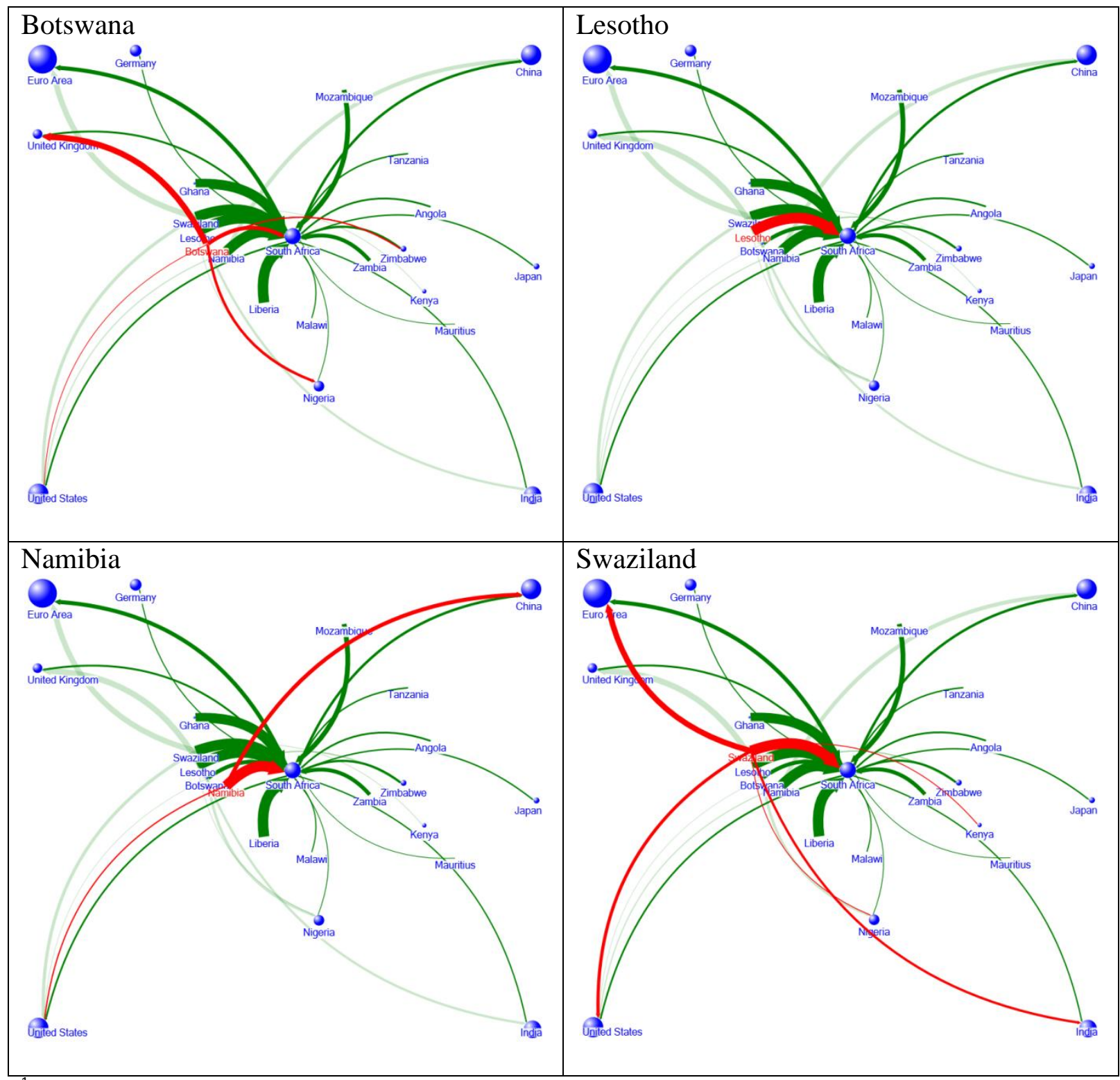

${ }^{1}$ Arrows indicate direction of trade. Red lines indicate exports to corresponding SACU country. Green lines represent bilateral trade of other sub-Saharan Africa countries. Arrow width represents bilateral trade size in percent of exporters GDP. 
BLNS countries do have direct trade linkages to advanced economies, but their main trading partners do not coincide. The euro area is an important market destination for South Africa and Swaziland. China is a relevant market for Namibia and South Africa. India is a relevant market for South Africa and Swaziland. In turn, the United States is an important market destination for all countries (Figure 5).

\section{Figure 5. Key Global Partners: Trading Network with SACU Partners, 2010 ${ }^{1}$}

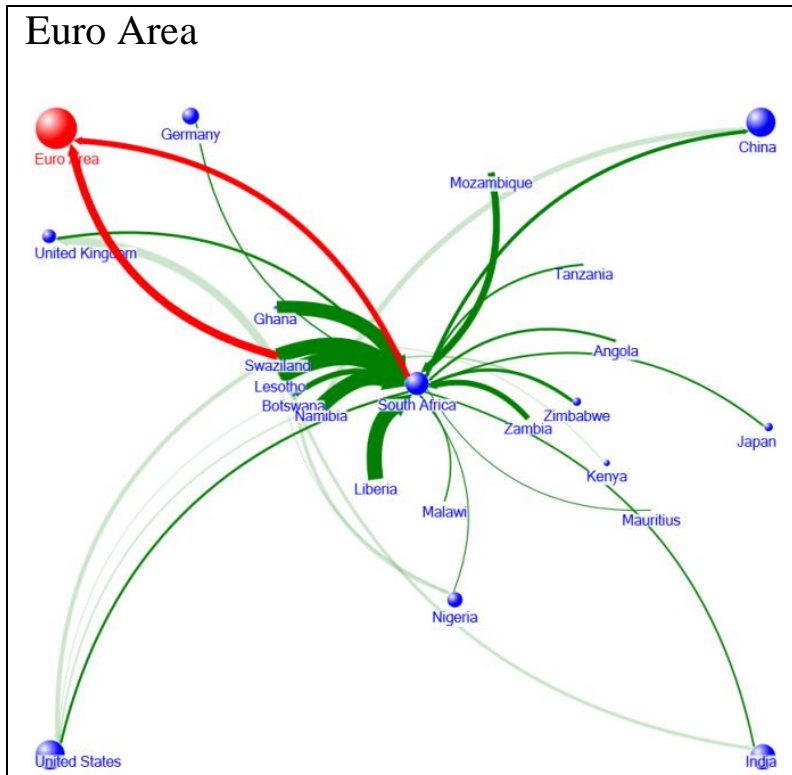

\section{China}

\section{United States}
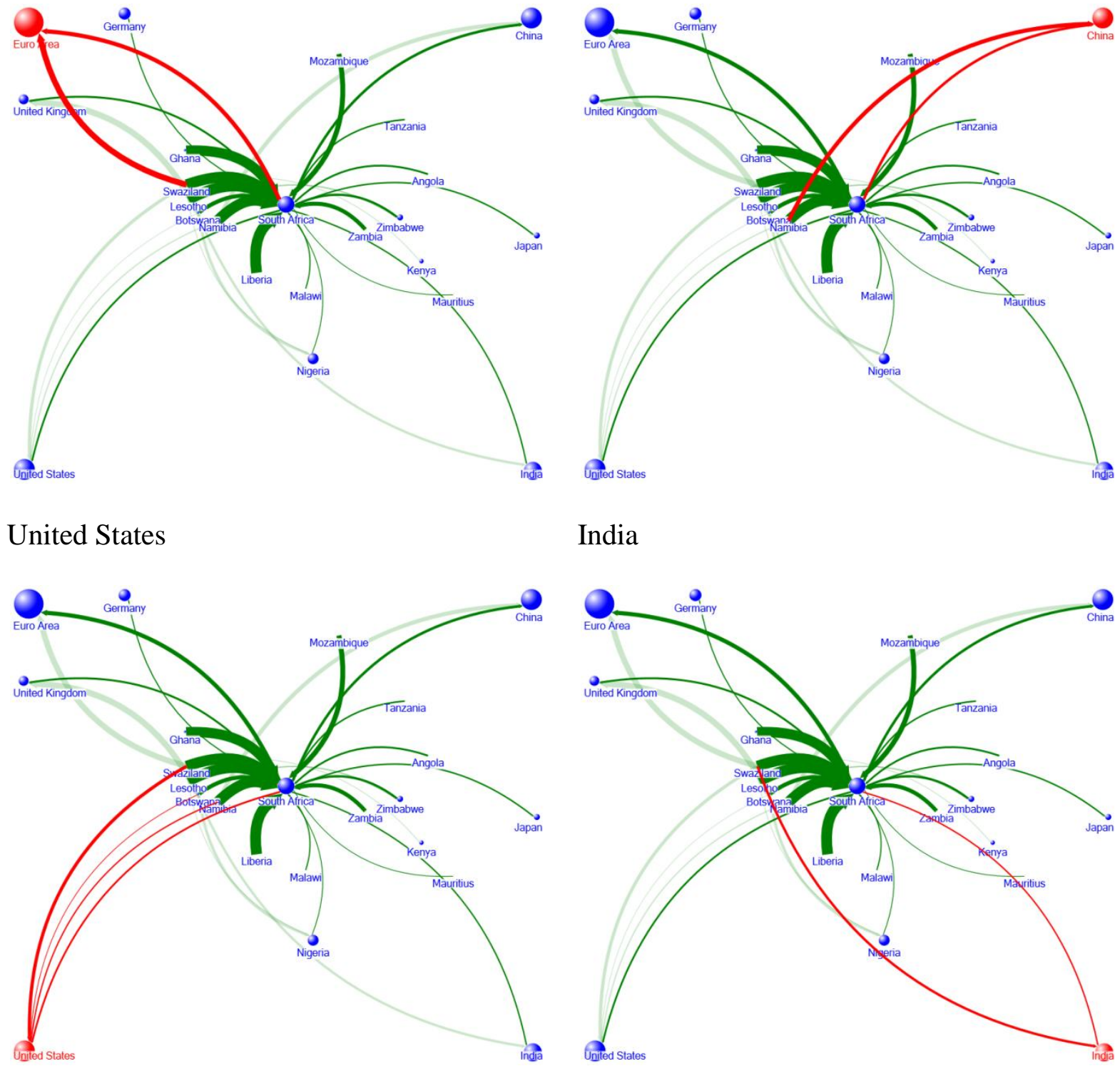

\section{India}

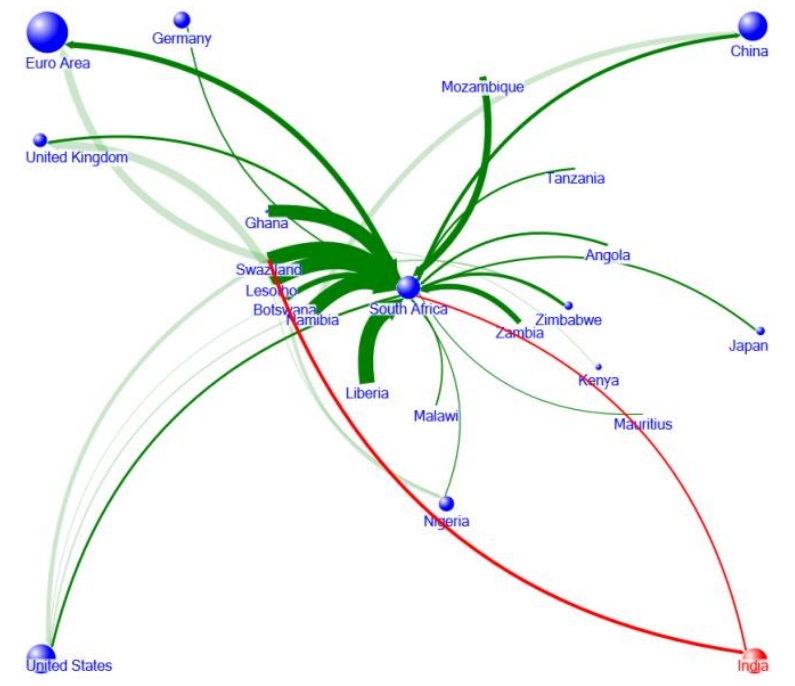

${ }^{1}$ Arrows indicate direction of trade. Red lines indicate exports from corresponding key global partner. Green lines represent bilateral trade of other sub-Saharan Africa countries. Arrow width represents bilateral trade size in percent of exporters GDP. 


\section{B. Current Account Receipts}

How do BLNS countries afford to have sustainable negative trade deficits? They have other significant current account receipts. In particular, exports amount to only about 40 percent of Lesotho's current account receipts, and about 65-70 percent in Namibia and Swaziland (Table 2).

Table 2. Sub-Saharan Africa: Composition of Current Account Receipts, 2010 ${ }^{1}$ (Percent of GDP)

\begin{tabular}{|c|c|c|c|c|c|c|c|}
\hline & $\begin{array}{l}\text { Total CA } \\
\text { revenue }\end{array}$ & $\begin{array}{l}\text { Exports } \\
\text { of good }\end{array}$ & $\begin{array}{l}\text { Exports of } \\
\text { services }\end{array}$ & $\begin{array}{l}\text { Income } \\
\text { Receipts }\end{array}$ & $\begin{array}{l}\text { Official } \\
\text { Transfers }\end{array}$ & $\begin{array}{l}\text { Private } \\
\text { Transfers }\end{array}$ & $\begin{array}{l}\text { Share of good } \\
\text { exports }\end{array}$ \\
\hline \multicolumn{8}{|l|}{$\underline{S A D C}$} \\
\hline \multicolumn{8}{|l|}{ SACU } \\
\hline South Africa & 28.0 & 23.5 & 3.8 & 1.3 & -0.7 & & 84 \\
\hline Botswana & 37.4 & 30.9 & 2.1 & 1.3 & 3.1 & & 83 \\
\hline Lesotho & 102.0 & 39.3 & 1.6 & 36.4 & 17.4 & 7.3 & 39 \\
\hline Namibia & 55.3 & 35.1 & 7.3 & 2.3 & 10.4 & & 64 \\
\hline Swaziland & 66.0 & 47.1 & 7.1 & 9.5 & & 2.0 & 71 \\
\hline
\end{tabular}

Source: IMF's World Economic Outlook Database.

${ }^{2}$ Color code: White (below 1 percent), green (between 1 and 10 percent), orange (between 10 and 20 percent), red (above 20 percent).

\section{Foreign aid}

South Africa does not provide foreign aid to the region, but aid from OECD countries is significant source of income in Lesotho, and to a lower degree in Namibia and Swaziland (Table 3).

Table 3. Sub-Saharan Africa: Official Development Assistance from OECD Countries (Percent of GDP and U.S. dollars, as indicated)

\begin{tabular}{|c|c|c|c|}
\hline & U.S. dollars & GDP & Percent of GDP \\
\hline \multicolumn{4}{|l|}{$\underline{S A D C}$} \\
\hline \multicolumn{4}{|l|}{ SACU } \\
\hline South Africa & $1,211.4$ & 363.7 & 0.3 \\
\hline Botswana & 120.3 & 14.9 & 0.8 \\
\hline Lesotho & 261.9 & 2.3 & 11.3 \\
\hline Namibia & 395.2 & 11.7 & 3.4 \\
\hline Swaziland & 125.9 & 3.7 & 3.4 \\
\hline
\end{tabular}

Source: OECD Stat. 


\section{Remittances}

For Lesotho, and to a lower degree, Swaziland, South Africa is a significant source of remittances and worker's compensation. Ratha and Shaw (2007) estimate that remittances from South Africa to Lesotho amounted to 20 percent of Lesotho GDP. A significant amount of these come from Lesotho people working at South African mines. Although the amount of remittances is large in percent of GDP, they have fallen by about 50 percent over the last 10-15 years, in line with the secular decline in gold production in South Africa (Table 4).

Table 4. Sub-Saharan Africa: Remittances, $2010^{1}$ (Percent of recipient's country GDP)

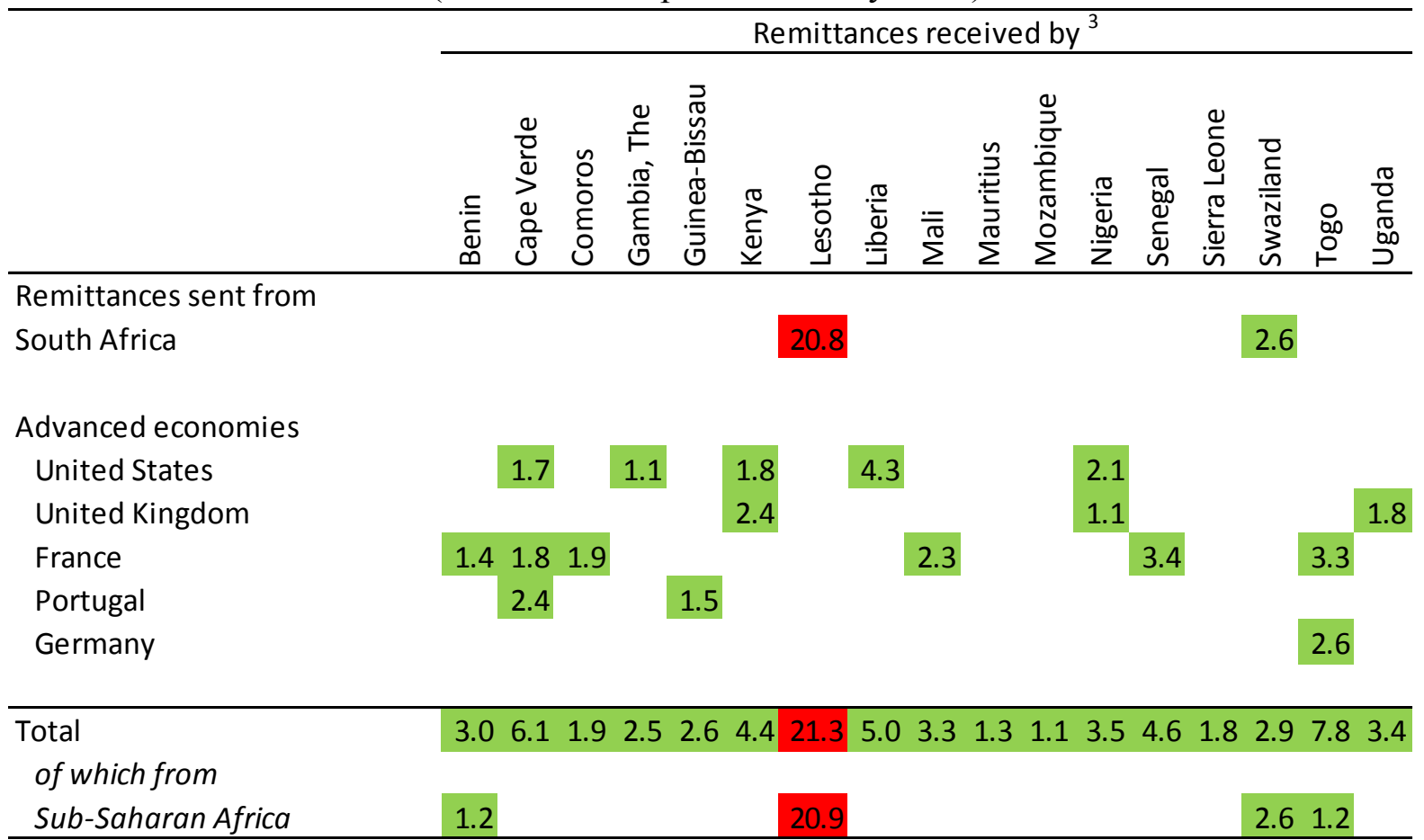

Source: Ratha and Shaw, 2007, "South-South Migration and Remittances," Development Prospects Group, World Bank and IMF's World Economic Outlook Database.

${ }^{1}$ Figures for other SSA countries are less than 1 percent of GDP or not available.

${ }^{2}$ Color code: White (below 1 percent), green (between 1 and 10 percent), orange (between 10 and 20 percent), red (above 20 percent).

3 Data for remittances for Zimbabwe are not available, although Zimbabwe has a large number of migrants working in South Africa.

\section{Foreign Direct Investment}

South Africa is the largest source of foreign direct investment for the BLNS countries. Nevertheless, it is relatively more important for the smaller countries (Table 5). South African nonfinancial firms are present not only within the BLNS countries, but more broadly within the Southern African Development Community (Table 6). This strong presence, together with the fact that many of these countries have substantial amounts of current 
account revenues, other than exports, allows South Africa to typically have a positive trade surplus in the region.

\section{Table 5. Sub-Saharan Africa: Foreign Direct Investment Stocks from Selected Countries, 2010}

(Percent of GDP)

\begin{tabular}{|c|c|c|c|c|c|c|c|c|c|}
\hline & \multirow{2}{*}{ European } & \multicolumn{4}{|c|}{ Of which } & \multirow[t]{2}{*}{ United States } & \multirow[t]{2}{*}{ China } & \multirow[t]{2}{*}{ South Africa } & \multirow[t]{2}{*}{ Total } \\
\hline & & France & Portugal & United Kingdon & Other & & & & \\
\hline \multicolumn{10}{|l|}{$\underline{S A D C}$} \\
\hline \multicolumn{10}{|l|}{ SACU } \\
\hline South Africa & 35.5 & 1.0 & 0.1 & 12.9 & 21.5 & 23.2 & 1.1 & $\ldots$ & 59.9 \\
\hline Swaziland & 3.5 & 0.0 & 0.0 & 0.1 & 3.4 & 0.1 & $\ldots$ & 11.1 & 14.7 \\
\hline Botswana & 3.0 & 0.0 & 0.0 & 2.4 & 0.6 & 0.5 & 1.2 & 3.3 & 8.0 \\
\hline Namibia & 2.6 & 0.0 & 0.0 & 0.0 & 2.6 & 0.0 & 0.4 & 4.3 & 7.4 \\
\hline Lesotho & 0.7 & 0.0 & 0.0 & 0.5 & 0.3 & 0.1 & 0.4 & 2.7 & 4.0 \\
\hline
\end{tabular}

Source: Bank of International Settlements

\section{Table 6. Sub-Saharan Africa: Key Nonfinancial South African Firms Operating in the} Region

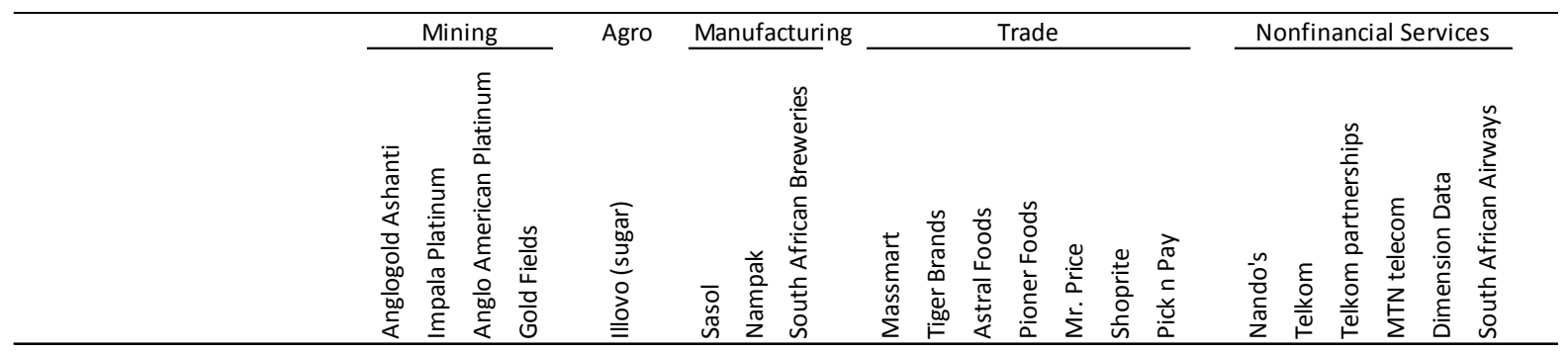

\begin{tabular}{|c|c|c|c|c|c|c|c|c|c|c|c|c|c|c|c|c|c|c|c|c|c|}
\hline \multicolumn{22}{|l|}{ SACU } \\
\hline South Africa & $x$ & $x$ & $x$ & $x$ & $x$ & $x$ & $x$ & $x$ & $x$ & $x$ & $x$ & $x$ & $x$ & $x$ & $x$ & $x$ & $x$ & $x$ & $\mathrm{x}$ & $x$ & $x$ \\
\hline Botswana & & & & & & & $x$ & $x$ & $\mathrm{x}$ & & & $x$ & $x$ & $x$ & $x$ & $x$ & & $\mathrm{x}$ & $x$ & $x$ & $x$ \\
\hline Lesotho & & & & & & & & $x$ & $x$ & & & & $x$ & $x$ & & & & $x$ & & & $x$ \\
\hline Namibia & $x$ & & & & & & $x$ & & $x$ & & & $x$ & $x$ & $x$ & $\mathrm{x}$ & $x$ & $x$ & $\mathrm{x}$ & & $x$ & $x$ \\
\hline Swaziland & & & & & $x$ & & $x$ & $x$ & $x$ & & $x$ & & & $x$ & & $x$ & & & $x$ & & $x$ \\
\hline Angola & & & & & & & $x$ & $x$ & & & & & & $x$ & & & & $x$ & & $x$ & $x$ \\
\hline Congo, Democratic Republic of & $\mathrm{x}$ & & & & & & & & & & & & & & & & & $x$ & & & $x$ \\
\hline Malawi & & & & & $x$ & & $x$ & $x$ & $x$ & & & & $x$ & $x$ & & $x$ & & $x$ & & $x$ & $x$ \\
\hline Mauritius & & & & & & & & $\mathrm{x}$ & $x$ & & $x$ & & $x$ & $\mathrm{x}$ & $x$ & $\mathrm{x}$ & & & & $\mathrm{x}$ & $\mathrm{x}$ \\
\hline Mozambique & & & & & $x$ & & $x$ & $x$ & $x$ & & $x$ & & $x$ & $x$ & $x$ & & & $x$ & & & $x$ \\
\hline Seychelles & & & & & & & & & & & & & & & & & & & & & \\
\hline Zambia & & & & & $x$ & & $x$ & $x$ & $x$ & & $x$ & $x$ & $x$ & $x$ & $x$ & $x$ & & $x$ & $x$ & & $x$ \\
\hline Zimbabwe & & $x$ & $x$ & & & & $\mathrm{x}$ & $x$ & & $x$ & & & & $\mathrm{x}$ & $\mathrm{x}$ & $x$ & $x$ & $x$ & & $x$ & $x$ \\
\hline Tanzania & $x$ & & & & $x$ & & $\mathrm{x}$ & $x$ & $x$ & & & & $x$ & $x$ & & & $\mathrm{x}$ & $x$ & & $x$ & $x$ \\
\hline$\underline{E A C}$ & & & & & & & & & & & & & & & & & & & & & \\
\hline$\overline{\text { Burundi }}$ & & & & & & & & & & & & & & & & & & $\mathrm{x}$ & & & $x$ \\
\hline Kenya & & & & & & & $x$ & $x$ & & $x$ & & & $x$ & & & & $x$ & $\mathrm{x}$ & & $x$ & $x$ \\
\hline Rwanda & & & & & & & & & & & & & $x$ & & & & & $x$ & $\mathrm{x}$ & & $x$ \\
\hline Uganda & & & & & & & & $x$ & $x$ & & & $x$ & & $x$ & & & $x$ & $x$ & $x$ & $x$ & $x$ \\
\hline Other & & & & & & & & & & & & & & & & & & & & & \\
\hline Ghana & $x$ & & & $\mathrm{x}$ & & & & $x$ & $x$ & & & & & $x$ & & & $x$ & & $x$ & $x$ & $x$ \\
\hline Nigeria & & & & & & $x$ & & $x$ & $x$ & & & & & $x$ & & $x$ & $x$ & & $x$ & $x$ & $x$ \\
\hline
\end{tabular}




\section{Financial}

South African foreign direct investment is not just limited to nonfinancial firms. South Africa has a strong presence in the entire SADC region, the East African community, in Ghana, and in Nigeria. Most of these countries have in common the strong presence of South African firms, suggesting that South African banks have been following their customers (Table 7).

Table 7. Sub-Saharan Africa: Selected Pan-African Financial Groups, 2011 (Share of deposits in 2010)

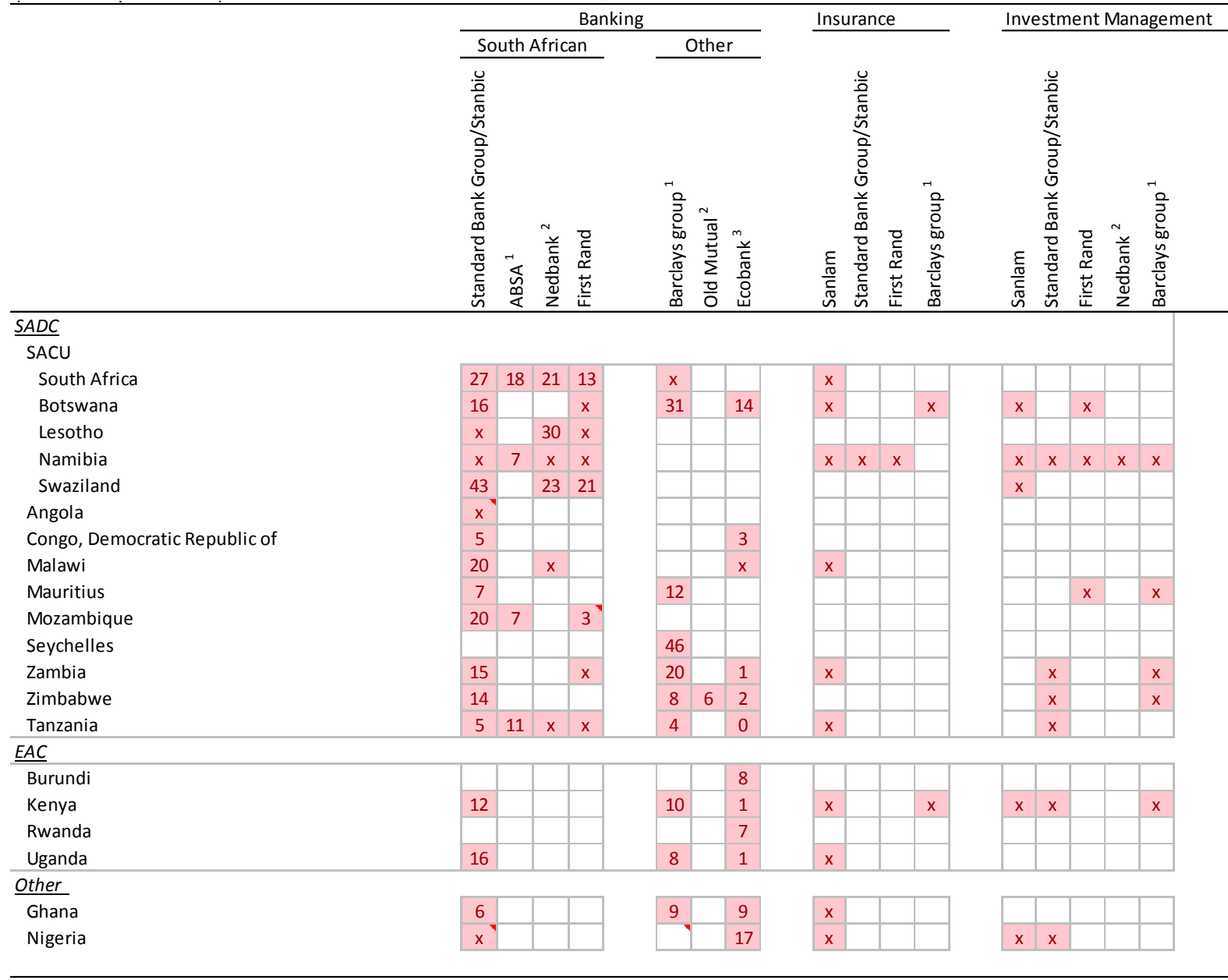

Sources: Annual Reports, BankScope, Bankers Almanac, and bank websites.

${ }^{1}$ Absa is a South African subsidiary of the British Barclays group.

${ }^{2}$ Nedbank Is a South African subsidiary of a British financial group Old Mutual.

${ }^{3}$ Nedbank has a cooperation agreement with Ecobank that allows it to use the facilities of each other to conduct banking business in the country in which one of them does not operate.

Within the SACU region, South Africa is not a source of cross border funding. On the contrary, despite the presence of South African subsidiaries in their countries, Lesotho, Namibian, and Swaziland residents hold cross border deposits in South Africa (Table 8). 
Table 8. Sub-Saharan Africa: Cross-border Banking Operations with South Africa, $2010^{1}$

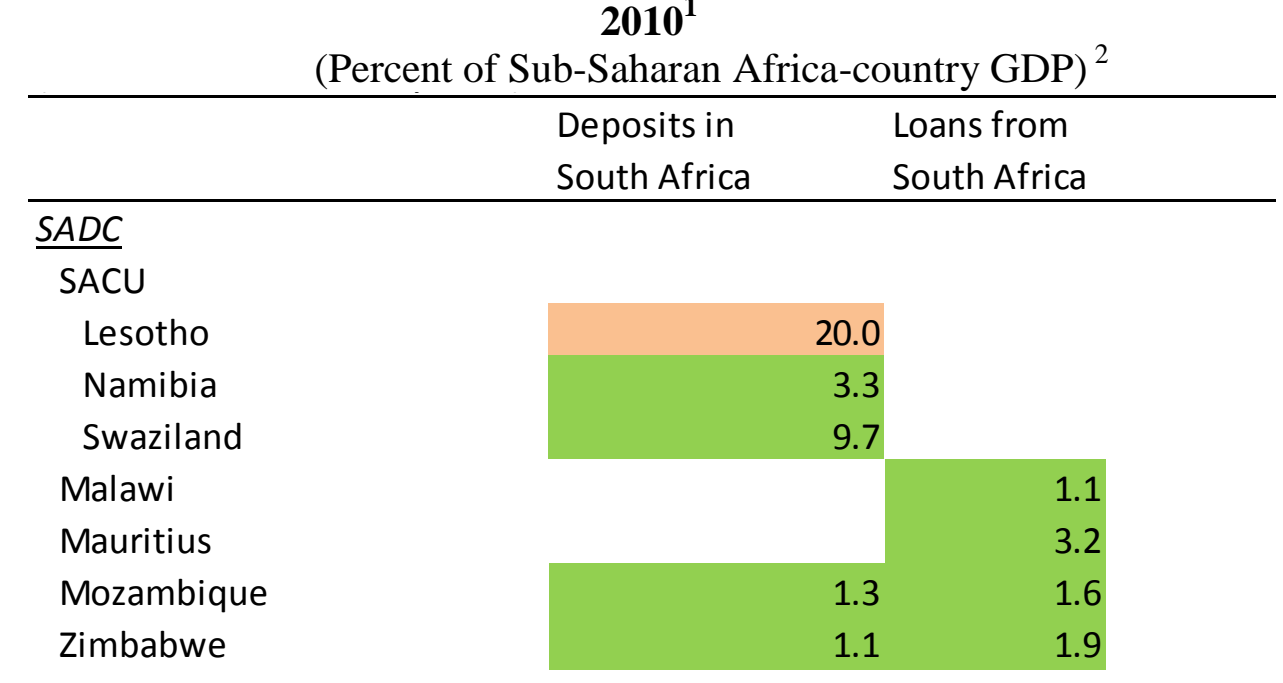

Source: Bank of International Settlements, locational banking Statistics.

${ }^{1}$ Includes only figures for which the stocks exceed 1 percent of the SSA-country's GDP.

${ }^{2}$ Color code: White (below 1 percent), green (between 1 and 10 percent), orange (between 10 and 20 percent), red (above 20 percent).

\section{E. Monetary and Exchange Policies}

South African monetary policy could potentially have important effects on economic activity in the region. South Africa, Lesotho, Namibia, and Swaziland form the Multilateral Monetary Area, with the rand circulating freely and LNS currencies pegged to the rand. Botswana's currency has traded closely to the rand. As a result, South Africa de facto decides monetary policy in the region. Its high degree of exchange rate flexibility serves as a shock absorber, but in uncertain global times gives rise to volatility in tradable prices.

\section{F. Fiscal Policies and Customs Revenue Sharing}

The Southern Africa Customs Union is the oldest customs union in the world. The sharing of customs revenues is a significant source of interlinkages among the SACU members. Since 2002, the revenues have been distributed according to a formula that depends on the amount of intraregional trade of each country. To grant some stability to these flows, the BLNS countries receive each fiscal year from South Africa a fixed amount of revenue on the basis of the expected customs revenue for the region. The difference between the expected and the actual amount of revenue is settled ex post. The linkage to South Africa arises because the total customs revenues to be distributed depend critically on the amount South Africa imports from the world. In turn, this partly depends on global developments that affect global trade 
and financial conditions, but also from monetary, fiscal, and financial policies that South Africa adopts and political and social events that may disrupt economic conditions.

Because imports are typically more volatile than overall economic activity, and because tax bases in the smaller BLNS countries are small, the revenue sharing formula results in sharp volatility in fiscal revenue in the region. If not managed carefully, this volatility could in principle lead to sharp volatility in real activity, or give rise to undue fiscal stress during downturns. For instance, custom revenues increased sharply during the boom ahead of the global financial crisis, shortly after the revenue formula was negotiated. As a result, fiscal revenue increased sharply, and in some countries fiscal spending followed with a lag (Figure 6). Later, the fall in customs revenues following the global finanical crisis resulted in a drop in customs revenue in Lesotho of about 20 percent of GDP and about 15 percent of GDP in Swaziland. The drop in customs revenue in Swaziland triggered a fiscal deficit and severe fiscal stress (Figure 7).
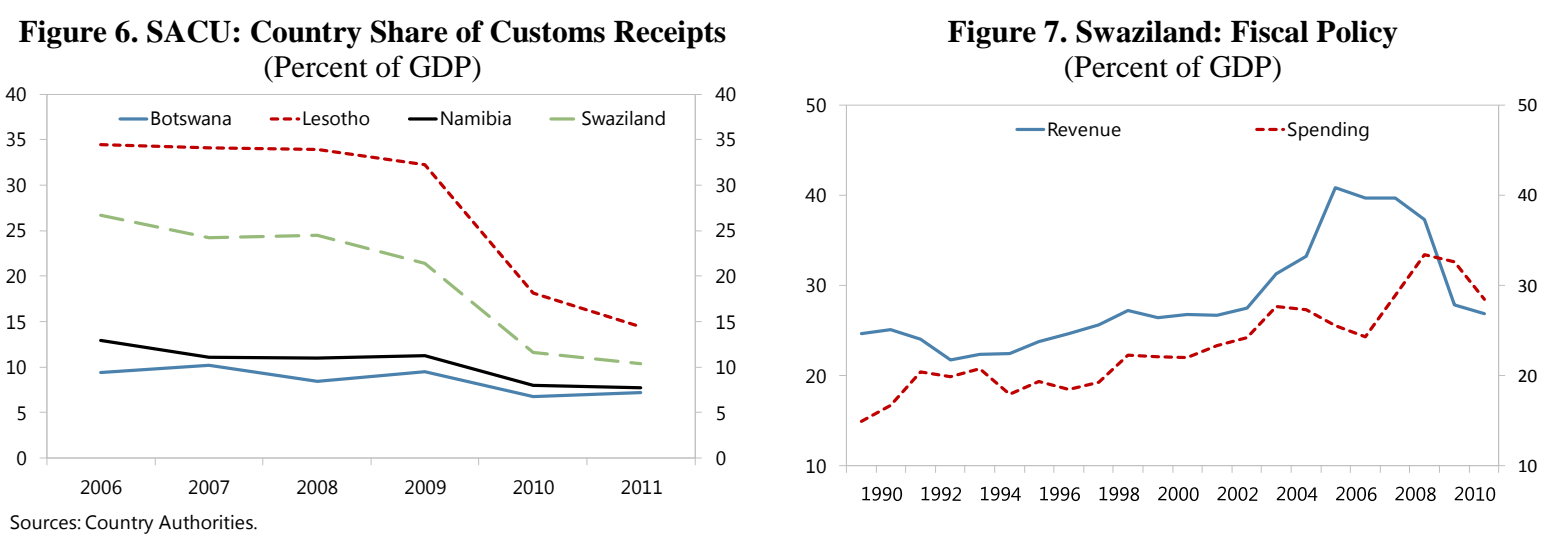

\section{MACROECONOMIC COMOVEMENTS}

Despite these interlinkages, contemporaneous correlations in real GDP growth between SACU countries and the world economy are relatively small, with the exception of South Africa (Table 9). In addition, the correlation between growth in the BLNS countries and South Africa is even smaller, and for the smaller and more exposed countries, the correlation is actually negative (Table 10). The same pattern emerges for growth in real domestic demand and gross national income.

The comovement is significantly stronger at the nominal level, particularly in dollar terms. Dollar GDP and GNI in the SACU region strongly comove with world dollar GDP and GNI. In turn, the correlation of the BLNS countries with South Africa is also very large. Dollar exports and imports are not as correlated as GDP and GNI, but significantly more closely related than in real terms. Not surprisingly, by pegging or closely tracking the rand exchange rate, together with the high dependence on imports from South Africa, inflation developments are closely related. 


\section{Table 9. Sub-Saharan Africa: Contemporaneous Correlation with World Macroeconomic Developments, 1990-2011 ${ }^{1}$}

GDP Real DD Real GNI Dollar GDP Dollar GNI Nominal exports Nominal Imports Inflation

\begin{tabular}{lr}
$\frac{S A D C}{S A C U}$ & \\
South Africa & 0.8 \\
Botswana & 0.4 \\
Lesotho & 0.1 \\
Namibia & 0.5 \\
Swaziland & 0.1 \\
& \\
\hline Source: IMF's World Economic Outlook Database. \\
${ }^{1}$ Color code: red for correlation higher than 0.5.
\end{tabular}

Table 10. Sub-Saharan Africa: Contemporaneous Correlation with South African Macroeconomic Developments, 1990-2011 ${ }^{1}$

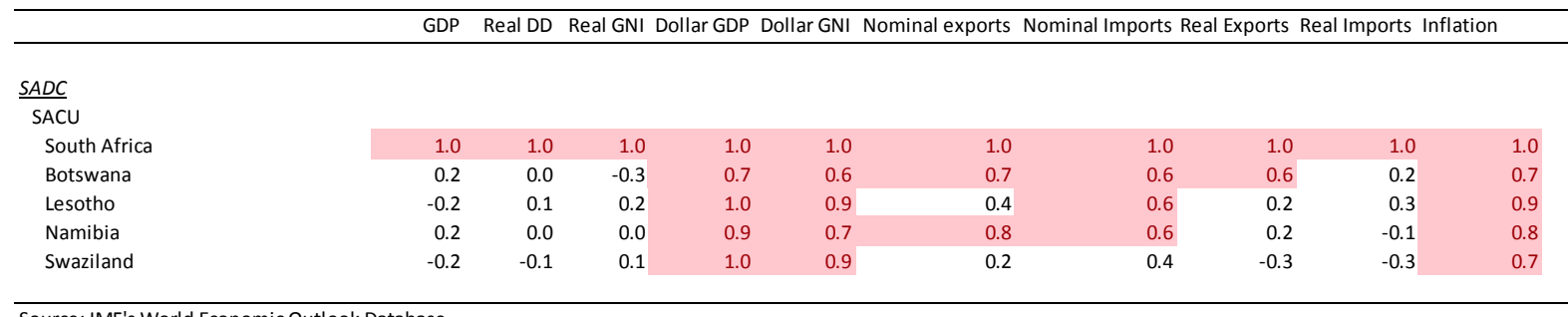

Source: IMF's World Economic Outlook Database.

${ }^{1}$ Color code: red for correlation higher than 0.5.

\section{REVIEW OF LITERATURE}

A common message from different studies on spillovers is that the impact on growth from a global slowdown and changes in commodity prices depends on the strength of trade and financial linkages. An IMF study (World Economic Outlook, April 2007, Chapter 4) shows that on average a 1 percentage point decline in GDP growth in the Euro area is associated with a slowing in GDP growth of about 0.25 percentage point in sub-Saharan Africa as a whole. Several studies have attempted to analyze growth factors (including exogenous shocks) using variants of structural cross-country growth regressions. Ndulu and O'Connell (2007) estimated the impact of exogenous shocks (income effects of terms of trade and growth in trading partners) on the growth rate of African economies and find a rise in trading partner growth rates is a positive shock to the economy. Similarly, income effects of terms of trade changes likewise have the expected positive effect on growth, though with a small coefficient.

Studies that focused on commodity prices and terms of trade such as Deaton and Miller (1996) for Africa and Raddatz (2007) for low income countries find that a surge in commodity prices significantly raises growth. Deaton finds that a decline in non-fuel commodity prices of 10 percent could reduce growth in sub-Saharan Africa by about 1.5 percent. Collier and Goderis (2007) however, find that while positive terms of trade shocks may have positive short-term effects on output they have adverse ones in the longer term in countries that do not have good institutions. 


\section{Panel Data Evidence}

The BLNS countries could arguably be part of an economic block given the strong real and financial interlinkages, sharing of monetary arrangements, free use of the South African rand, and the custom's revenue sharing formula. As such, they may react to the external environment in a similar way, with fiscal policies and differences in economic structure providing some room for different country outcomes. Developments in South Africa may reasonably play some role in explaining the economic conditions in the region.

To pursue this idea further, this section estimates dynamic panel growth regressions for the BLNS countries using the generalized method of moments (Arellano-Bond, 1991). The independent variables include world growth, oil prices, interest rate spreads, fiscal balances, and country fixed effects. The panel also includes lagged dependent variables to ascertain the degree of persistence. It focuses on quantifying the impact of variations in both world growth, South African growth and commodity prices/terms of trade and uses annual data to better capture shorter-run business cycle spillovers. To estimate the impact of a global slowdown on BLNS countries, dynamic panel growth regressions were estimated relating real growth in domestic output to growth in the rest of the world, growth in South Africa, and with several control variables: terms of trade, openness, fiscal balance, global financial conditions, and country specific effects. The sample covers 5 countries and uses annual data for 1986-2010 (see the appendix for a description of data and sources).

A panel data approach is used on account of the analysis's limited period of coverage. Furthermore, panel data have advantages over cross section or time-series data, in that they make it possible to account for latent heterogeneity and to reduce standard errors of point estimates (efficiency gains). The following equation was estimated using generalized method of moments estimators (GMM) of Arellano and Bond (1991).

$$
y_{i t}=\sum_{j=1}^{k} \alpha_{j} X_{i t}^{j}+\rho y_{i t-1}+u_{i t}
$$

where:

$\mathrm{y} \quad$ is the real GDP growth rate;

$X_{i t}^{j}=\mathrm{j}^{\text {th }}$ explanatory variable, $\mathrm{j}=1 \ldots \mathrm{K}$, a vector of macroeconomic variables explaining changes in growth rate;

$\alpha_{j} \quad$ are the parameters to be estimated;

$y_{i t-1}$ represent the growth rate lagged by one period;

$u_{i t}=\alpha_{i}+\varepsilon_{i t}, \alpha=$ country-specific effects (country-specific intercept) accounting for heterogeneity in the group of countries under consideration;

$\varepsilon=\quad$ error term; $\mathrm{i}=1 . . .4$ (four country index); $\mathrm{t}=1 \ldots \mathrm{T}($ time index $) ;$ and

The main independent variables are as follows:

- $\quad$ The lagged dependent variable to ascertain the degree of persistence. 
- World growth: BLNS countries are affected by lower external demand for their exports. World growth can capture the effect of global slowdown.

- South African growth: To capture the impact of South Africa on the BLNS countries, being a major trading partner for these countries.

- $\quad$ Terms of trade. The main advantage of using the terms of trade is that it can be considered to be exogenous; members of BLNS have limited power over their terms of trade, as the prices of their exports (primary commodities) are determined in the world markets and their imports are mostly manufactured goods produced by industrial countries.

- Openness. Defined as the ratio of exports of goods and services plus imports of goods and services to GDP. Openness increases a country's exposure to and vulnerabilities to external shocks, which lower revenue. At the same time, openness could be favorable to growth through its impact on TFP, thereby enhancing revenue performance.

- $\quad$ Fiscal deficit: Counter-cyclical fiscal policies (expenditure induced) could be positive for growth.

- $\quad$ Financial condition: Proxied by the spread of 3-month LIBOR vs. US Treasury bills. Unfavorable financial conditions are expected to be negative for growth.

The main finding is that global developments matter, but so do domestic policies. At the global level, real and financial factors (which can safely be considered exogenous to the region) exert a significant influence on the region.

- $\quad$ First, panel estimates suggest a slowdown in world growth has tended to slow growth in BLNS countries. Moreover, this effect seems to have been contemporary. In particular, a 1 percentage point slowdown world growth has on average cut growth in BLNS countries by 0.6 percentage points. This result is robust across various alternative specifications.

- Second, higher income from better terms of trade has tended to boost growth in the region.

- $\quad$ Third, higher global banking interest rates tend to have taken a toll on growth in the region. An increase in the so-called TED spread, which measures the spread between the 3-month LIBOR and U.S. treasury bills, lowers growth rates in the BLNS countries.

The panel suggests that fiscal policies have made a difference in the region. While the global variables affect all BLNS countries in the same way under the panel, country differences in part reflect differences in fiscal policies. The results are consistent with effective 
countercyclical fiscal policies, in that a 1 percentage point decrease in fiscal balance (expenditure induced) increases growth by 0.25 percent (Table 11).

\section{Table 11. Explaining Growth in BLNS Countries \\ (GMM regression output for real GDP Growth)}

\begin{tabular}{|c|c|c|}
\hline & $\begin{array}{c}\text { Equation 1 } \\
\text { (VCE-robust) }\end{array}$ & $\begin{array}{c}\text { Equation 2 } \\
\text { (VCE-GMM) }\end{array}$ \\
\hline Intercept & $\begin{array}{c}-1.72 \\
(-2.29)^{* *}\end{array}$ & -1.72 \\
& -0.16 & $-0.57)$ \\
\hline Real GDP growth (t-1) & $(-1.24)$ & $(-1.30)$ \\
\hline World Growth & 0.63 & 0.63 \\
& $(3.78)^{* * *}$ & $(2.73)^{* * *}$ \\
\hline Fiscal deficit & 0.26 & 0.26 \\
& $(6.19)^{* * *}$ & $(2.23)^{* *}$ \\
\hline Level terms of trade & 0.03 & 0.03 \\
& $(6.58)^{* * *}$ & $(1.1)^{*}$ \\
\hline Financial condition & -1.37 & -1.37 \\
& $(-3.56)^{* * *}$ & $(-2.21)^{* *}$ \\
\hline Number of observations & 88 & 88 \\
\hline AR(1) test: p-value & 0.07 & 0.49 \\
\hline AR(2) test: p-value & 0.14 & \\
\hline Sargan test: $p$-value & & \\
\hline$* *$ denotes significant at 1 percent level; \\
** denotes significant at 5 percent level; \\
$*$ denotes significant at 10 percent level
\end{tabular}

The panel also suggests that, once global developments and domestic fiscal policies are considered, the evolution of South African GDP growth has not contributed to the systematic growth developments of the region as a whole. South African growth is stastistically not significant. In alternative specifications to test the robustness of this result, neither real domestic demand growth or real exchange rate developments were significant.

External openness, defined as the ratio of exports of goods and services plus imports of goods and services to GDP, was not significant in the panel. This may reflect that opennes may have mixed effects on growth. On the one hand, it increases a country's exposure to and vulnerabilities to external shocks. At the same time, openness could be favorable to growth through its impact on TFP, thereby enhancing revenue performance.

\section{SPILLOVERS EVIDENCE FROM VECTOR AUTOREGRESSIONS}

To shed light on the probable country differences, especially in country dynamics, we also estimate vector-autoregressive (VAR) models. We focus on the relationship between growth in BLNS countries and selected developments in South Africa, after controlling for world 
growth. In particular, we try to find how growth in South Africa's GDP or domestic demand affects growth in BLNS countries. We also explore what role South Africa's real exchange rate may play.

For each country (i), we estimate VARs of the following form:

$$
Y_{i, t}=\sum_{j=1}^{m} A_{i j} Y_{i, t-j}+\varepsilon_{i, t}
$$

where $Y_{\text {it }}$ is a vector of four endogenous variables: (i) the world real GDP growth; (ii) South Africa's domestic demand growth or real GDP growth; (iii) South Africa's real exchange rate; and $(i v)$ the real growth rate for BNLS country $i$. In turn, $\mathrm{A}_{\mathrm{ij}}$ is a vector of coefficients, $\varepsilon_{t}$ is a vector of error terms. The m lags in the system are country specific and determined by the lag information criteria that yielded the lowest number of lags, given the low degrees of freedom. To estimate impulse responses and variance decompositions, we used the Cholesky decomposition method to orthogonalize the shocks, using the order in which the variables were presented above. This assumes world economic growth is the most exogenous variable.

The annual data covers the period 1986-2010. Data for the real GDP growth rates for the BLNS countries, South Africa and the world economy comes from the IMF September 2011 World Economic Outlook database. So does South Africa's domestic demand growth. South Africa's real exchange rate data comes from the IMF's Information Notice system database.

From the impulse responses, we conclude that events that affect world growth spill over into GDP growth of most BLNS countries, with the exception of Lesotho. South Africa's real GDP growth does not seem to contribute much to GDP growth in these countries, after controlling for world growth, except for Lesotho. This does not necessarily mean there are no systematic spillovers from South Africa into BNS countries, and that at best, South Africa acts as a conduit without amplifying or mitigating the shocks. It means that spillovers may come from other channels.

The results for Lesotho are interesting because they suggest that growth in Lesotho falls when it increases in South Africa. While this may sound counterintuitive, it could reflect that workers from Lesotho migrate to South Africa when the South African economy is booming (lowering domestic production) and come back when South Africa is facing rough times.

What happens if you replace South Africa's real GDP growth with its real private domestic demand growth? World growth remains robustly significant in all countries but Lesotho. South Africa's real domestic demand becomes positively significant for Namibia and Swaziland, while for Lesotho it remains as negatively significant.

Does the South African real exchange matter? The real exchange rate volatility could potentially affect the real value of the intra SACU transfers, which adds significant resources to BLNS treasuries. These transfers are related to customs revenues, whose real purchasing value depends on the real exchange rate. An appreciation would reduce the real value of those transfers and vice versa. The impulse responses suggest that a real appreciation in 
South Africa tends to reduce growth in Bostwana perhaps by hurting competitiveness, but to increase it in Swaziland. It appears insignificant for Lesotho and Namibia. These results are robust to replacing real demand growth with real GDP growth (Table 12).

Table 12. Model 1 and 2-Impulse Response Functions

Model 1 Impulse response functions

\begin{tabular}{|l|c|c|c|c|}
\hline \multicolumn{5}{|c|}{ Impulse Response Functions } \\
\hline & World economic growth & South Africa economic growth & South Africa real exchange rate \\
\hline Botswana & $(+)^{*}$ & & $(-)^{*}$ \\
\hline Lesotho & & $(-)^{*}$ & \\
\hline Namibia & $(+)^{*}$ & & \\
\hline Swaziland & $(+)^{*}$ & & $(+)^{*}$ \\
\hline
\end{tabular}

Source: Authors' calculations

Notes:

1. * implies significancy of the impulse response functions.

2. Signs in brackets show the direction of the impulse response

3. All impulses are significant in the 1st period only.

Model 2. Impulse response functions

\begin{tabular}{|l|c|c|c|}
\hline \multicolumn{5}{|c|}{ Impulse Response Functions } \\
\hline & World economic growth & South Africa domestic demand growth & South Africa real exchange rate \\
\hline Botswana & $(+)^{*}$ & & $(-)^{*}$ \\
\hline Lesotho & & $(-)^{*}$ & \\
\hline Namibia & $(+)^{*}$ & $(+)^{*}$ & $(+)^{*}$ \\
\hline Swaziland & $(+)^{*}$ & $(+)^{*}$ & \\
\hline
\end{tabular}

Source: Authors' calculations

Notes:

1. * implies significancy of the impulse response functions.

2. Signs in brackets show the direction of the impulse response

3. All impulses are significant in the 1st period only.

What is the relative importance of world growth, South African developments (either in GDP or domestic demand growth), or the real exchange rate in affecting growth in BLNS countries? Variance decompositions suggest that world growth is the most important variable for Botswana, Namibia, and Swaziland. Moreover, its importance tends to increase in the case of Namibia and Swaziland. For Lesotho, South African developments in either GDP or domestic demand growth are the most important determinants in the short run (although as we have seen the relationship is negative). Over time, however, world economic growth and the South African real exchange rate gain importance. For Botswana and Swaziland, the importance of South Africa's real exchange rate also increases over time (Table 13). 
Table 13. Model 1 and 2 - Variance Decompositions

Model 1 Variance decompositions

\begin{tabular}{|c|c|c|c|}
\hline \multicolumn{4}{|c|}{ Variance Decomposition of BLNS growth rates (percentages of total) } \\
\hline & World economic growth & South Africa economic growth & South Africa real exchange rate \\
\hline \multicolumn{4}{|l|}{ Year 1} \\
\hline Botswana & 41.6 & 0.2 & 8.9 \\
\hline Lesotho & 1.0 & 41.4 & 3.3 \\
\hline Namibia & 21.0 & 0.6 & 3.5 \\
\hline Swaziland & 37.6 & 1.8 & 15.4 \\
\hline \multicolumn{4}{|l|}{ Year 5} \\
\hline Botswana & 30.5 & 5.6 & 30.5 \\
\hline Lesotho & 20.4 & 30.9 & 10.4 \\
\hline Namibia & 43.9 & 2.1 & 5.2 \\
\hline Swaziland & 38.7 & 2.4 & 29.9 \\
\hline
\end{tabular}

Source: Authors' calculations

Model 2 Variance decompositions

\begin{tabular}{|c|c|c|c|}
\hline \multicolumn{4}{|c|}{ Variance Decomposition of BLNS growth rates (percentages of total) } \\
\hline & World economic growth & South Africa domestic demand growth & South Africa real exchange rate \\
\hline \multicolumn{4}{|l|}{ Year 1} \\
\hline Botswana & 29.6 & 9.0 & 12.6 \\
\hline Lesotho & 10.1 & 18.2 & 1.4 \\
\hline Namibia & 17.6 & 16.0 & 2.8 \\
\hline Swaziland & 31.0 & 12.1 & 7.7 \\
\hline \multicolumn{4}{|l|}{ Year 5} \\
\hline Botswana & 19.7 & 11.1 & 39.4 \\
\hline Lesotho & 17.7 & 14.7 & 17.0 \\
\hline Namibia & 37.4 & 11.9 & 8.6 \\
\hline Swaziland & 36.6 & 6.8 & 29.9 \\
\hline
\end{tabular}

Source: Authors' calculations

\section{CONCLuSions}

Despite significant spillovers arising from real and financial interlinkages shocks to real GDP, growth in South Africa do not seem to systematically affect growth developments in BLNS countries as a group. The panel regressions suggest that the global real and financial environment affects all SACU members and that countercyclical fiscal policies can play a role to cushion their effect on the economy. Because financial systems in the other SACU countries (the BLNS) are much less developed than those in South Africa, the results could suggest that South Africa acts as a conduit in the transmission of the external environment (otherwise financial effects may be hard to explain), but it does not amplify or cushion these effects. Nevertheless, vector autoregressions, which allow country-specific parameters, suggest some strong growth spillovers to the smaller economies. 


\section{REFERENCES}

Arellano, M. and S. Bond. (April 1991). Some tests of specification for panel data: Monte Carlo evidence and an application to employment equations. The Review of Economic Studies, 58. pp. 277 - 297.

Collier, Paulo, and Benedikt Goderis, 2007, "Commodity Prices, Growth and the Natural Rresource Curse: Reconciling a Conundrum," University of Oxford.

Dabla-Norris, E., R. Espinoza, and S. Jahan, 2012, "Spillovers to Low-Income Countries Importance of Systemic Emerging Markets,” IMF Working Paper 12/49 (Washington)

Deaton, A., and Miller, R., 1996, "International Commodity Prices, Macroeconomic Performance and Politics in Sub-Saharan Africa," Journal of African Economies, Vol. 5, pp. 99-191.

Drummond, P., and Ramirez, G., 2009, "Spillovers from the Rest of the World into Sub-Saharan African Countries," IMF Working Paper 09/155 (Washington: International Monetary Fund).

Obiora, K. I., "Do Trading Partners Still Matter for Nigeria's Growth? A Contribution to the Debate on Decoupling and Spillovers" IMF Working Paper 09/218 (Washington)

Harris, R., and R. Sollis, 2003, “Applied Time Series Modeling and Forecasting,” New York: John Wiley and Sons.

International Monetary Fund, 2007, World Economic Outlook (Washington, April).

Ndulu, B., and S. O'Connell S., 2007, "Policy Plus: African Growth Performance, 1960-2000," in The Political Economy of Economic Growth in Africa, 1960-2000, ed. by Benno Ndulu, Stephen O'Connell, Robert Bates, Paul Collier, Chukwuma Soludo, Jean-Paul Azam, Augustin Fosu, Jan Willem Gunning, and Dominique Njinkeu (Cambridge, United Kingdom: Cambridge University Press).

Raddatz, C., 2008, "Have External Shocks Become more Important for Output Fluctuationsin African Countries?" in Africa at a Turning Point? Growth, Aid, and External Shocks, ed. by D. Go and J. Page (Washington: World Bank). 